\title{
Europe Without Europeans
}

\author{
Aleš Debeljak
}

In the 1990s, the European Union aimed to achieve two ambitious goals: to end the wars for Yugoslav succession and to lead the nations of former communist countries in Eastern Europe toward economic and social prosperity. Both of these goals remain elusive. The Dayton Accord, brokered by the United States in 1995, merely "froze" the state of war on the territory of former Yugoslavia without remedying its causes and without removing the conditions that facilitated it. Moreover, it was not a European, but an American military force that effectively intervened in Bosnia and then later in Kosovo. Indeed, only with a slight exaggeration do I say that Sarajevo would still be under siege today if the Yugoslav wars had remained the exclusive responsibility of the EU.

As for the second goal, the economic and social prosperity for post-communist countries, it is undeniable that the "velvet revolutions" of 1989 ushered in a period of renewed hope. Yet, the EU failed to respond with its version of the Marshall Plan, offering substantial and comprehensive assistance to these nations. The subsequent integration of many of these countries into the EU presents a grave political, cultural, and economic challenge. To put it bluntly: the mission of the EU to bring prosperity and stability into Eastern Europe and the Balkans is an expensive and contradictory enterprise. It is sure to keep the EU nations at odds for at least several generations to come. We are thus left with the dawning realization that Europeans may have tragically failed in the very objectives that they strove to realize on their own, that is, without outside (read: American) help.

From this angle, it seems all the more clear that the various channels connecting Europe and America reflect a real, mutual, often suspicion-filled, yet inescapable dependence. Suffice is to point out the trade networks between the EU and the United States, the density of which is only surpassed by the commercial traffic within EU, that is, among the EU members themselves. Despite the messianic self-righteousness of the American government under the president George W. Bush and the ill-justified occupation of Iraq in the spring of 2003, the community of European nations cannot simply retreat into their historical bunker of cultural specificities and try to define itself against America. The attempt to build a European political identity on anti-American foundations is, I fear, just as likely to fail as the past attempt of German Romantics to define their nation on an exclusively anti-French basis.

In addition, America has been much more systematic in providing support to Eastern European anti-communist dissidents and the fresh buds of civil society that sprouted there. From a historical vantage point, this is hardly a surprise. In the wake of World War II, Western Europe was a de facto American military protectorate. It is ironic that without the threat of war and without the American deterrence capabilities, Europeans would certainly not have been able to afford the massive investment, over half a century, into their political search for "universal peace". It was only under the protective umbrella of NATO with America at its helm, that Western Europe could begin the post-war project of reconciliation and integration.

During these years, Europe took ample advantage of the American aid intended to rebuild the destroyed continent. America provided European nations with the initial incentive to summon adequate political will to overcome the violent conflicts that had divided them for centuries. This endeavor required the strategic construction of common life-world structures that were meant to render war between European nations not only materially impractical, but also morally unacceptable and politically unfathomable. Despite progress in this direction, however, Europe failed to entirely eliminate obstacles on the complex map of historical hostilities, across which any idea of a community of European nations must navigate.

To conceive of Europe's imaginary totality is to draw identifiable boundaries. But the absence of a strict natural 
border on the eastern flank of the continent has, instead, conditioned the need for a symbolic geography. Distinct areas were and continue to be defined by mutual opposition. In other words, Europe has traditionally defined itself negatively, its self-perception arising from what it is not, rather than from what it is.

Accordingly, Europe's outer boundaries shifted with political circumstances and contingent features of different social-historical periods. At various times, this boundary has been determined by the Oder and Neisse rivers, by the ridges of the Carpathian Mountains, the Ural Mountains, the summits of the Alps and the Pyrenees, the Atlas mountains, the coasts of the Black and Caspian Seas, the Iron curtain, and, most recently, by the Schengen limes. Throughout the ongoing changes in the meaning that Europe has attributed to the imagined or real enemy, temporary alliances of interest and pragmatic coalitions of power were formed.

The smallest common denominator in a communal integration was fear. In the collective mind of the nations claiming membership in Europe, the West and the East have acquired polarized values. In modern times, it was Eastern Europe and the Balkans with the attendant communist ideology that assumed this negative role. In the Middle Ages, European rhetoric has persistently perceived Islamic culture as the "other" in its ongoing process of defining borders between the domestic and foreign, between us and them. After New York \& Washington's 9/11, Madrid's 3/11 and London's 7/7, it is the image of Islam as "the other", as the anti-Christian, anti-Western and antimodern threat, that was revived in a European public discourse.

The noble ambition that wants to see "free and united Europe" has since World War II inspired significant part of the national elites across the continent. These elites realized that they must limit the potential sources of fear, while at the same time striving to integrate diverse ethnic, cultural and social traditions into common structures. This ambition continues to drive many European leaders.

But where does Europe end? And who, really, is European? Will the citizens of post-communist countries, new members of the EU since May 2004 and January 2007, receive not only the political rights of European citizenship, but also the societal respect worthy of an association of equals? How long will it take to cast off the legacy of the traditionally divided continent?

And divided it was. Fifty years of cold war, sometimes called the third world war, profoundly affected the European mental landscape. Berlin Wall, erected between democratic capitalist West and totalitarian communist East was both, a fitting symbol and an instrument of a great divide. Its implications were that of a Manichean battle of ideas, of good versus evil. For this, a clear demarcation must exist between the two as it is a necessary precondition for the life of an ideological stereotype. Yet, the divide was a shifting one, an ongoing result of a negotiation about the meaning of good and evil between the two ideological camps: it was not an air-tight separation. As the West and the East attempted to outwit each other, cracks and fissures developed allowing people to create an imaginary Other out of scraps, bits and pieces of stories and images that oozed through the Wall. The process of mutual exchange was guided by the politics of suspicion, leading into a cul-de-sac of stereotypisation.

How long will then West Europeans need to overcome the deep-rooted feelings of suspicion (or at best apathy) that they feel toward the "barbaric" states and peoples of the East, this European terra incognita? How long will East Europeans behave like poor little relatives trying to impress? I wish I knew.

Sure, for some commentators the very idea of a "free and united Europe" provokes a condescending smile, but if history can possibly be of any use, than we could do worse than assimilate a lesson that it is equally laughable to contemplate a divided and, at the same time, successful Europe. A united Europe, of course, would be utterly unique. To the extent that the European Union does have many features of the state, it is a state of nations and not a nation of states, like the United States of America.

The EU is thus inventing a self-suitable political form as it goes along. The dream of a united Europe, however, is ancient. It was pursued by the Roman Empire, Charlemagne and Napoleon, but also by Hitler (and this is only a partial list). After World War II, the European idea was adopted by the institutions that were conceived to prevent future armed conflict on the continent. Regardless of the vantage point, one is left with the same conclusion: the European idea is indelibly scarred by wars, aggression and violent conflict.

In order for European citizens to gain a reflexive awareness of our shared history, the shaping of the politics of European identity is of paramount importance. Yet sober reflection calls for humility. The face of "Europeaness" is invisible. Distinctly European elements of one's identity are today not easy to pinpoint. Moreover, in order to have a vision for a progressive realization of European identity, the common goals of European integration would have to be defined if they are to serve as guidelines.

In view of the bickering inside the EU and the bitter disputes over the European constitution, alas, it is 
impossible to deduce with any certainty what are in fact the common goals of European integration. Does the goal lie in a particular vision of "Fortress Europe" which should close its doors after a reluctant welcome was extended in 2007 to "Balkan rhythm \& blues", Romania and Bulgaria? Or is the goal projected in Europe as the embodiment of universal ideas: the rule of law, the liberal democratic system, constitutional respect for human rights? A union that can and must expand, perhaps to Turkey and the southern coasts of the Mediterranean, if not to the countries lying east of Polish borders?

In an unstable environment of post-Cold War, the European Union appears to be perceived, at least among the elites and middle classes in the continent's eastern part, as the ultimate purpose of national life. This large segment of the public pins their hopes for quick improvement of living conditions on decidedly West European standards, but one fact won't disappear: despite the collapse of communism, Western Europe remains by and large a "family onto itself".

From this vantage point, four aspects in the genesis of contemporary Europe come to the fore. First, there is the economistic ideology that emerged from etatist political culture, based as it is on the belief that it is possible in a relatively short time to change individual behavior and values by changing market conditions. The second aspect lies in the fact that Europe defines itself negatively, as indicated above. The third aspect is the shared mental framework that might eventually nurture the commonality of European nations. At present, this frame is still weak, abstract and optional.

The "European joke" is a case in point. Consider: there are virtually no jokes about Europeans, in contrast to the cornucopia of jokes about individual nations. As stereotype-affirming as jokes tend to be, they do reveal the preoccupations of ordinary people in their everyday lives. A European is featured as neither the protagonist nor the butt of jokes for the simple reason that "Europeanism", the nascent identity in which to ground such a subject, is hardly present in public spheres of individual nation-states.

This brings us to the fourth key aspect of the current European order: its democratic deficit. United Europe remains the project of social elites rather than that of broader national constituencies. Due to the inescapable fact that the European Union is being established from the top down, it has yet to take full root among ordinary people. The European anthem, the flag, and the Euro banknotes are isolated bricks in the mental structure of the European identity; they need ligatures to hold them together.

In this light, we need to consider possibilities for constructing a common template for an inclusive European identity that will have a wide public appeal. But joint projects as the "Cultural Capital of Europe" program, which fosters mutual understanding between European nations; the Erasmus, Socrates, and Tempus scholarships, which are designed to encourage the sharing of scientific research; international human rights workshops; and support for efforts to build a democratic mentality in the public at large-all these and many other welcome forms of European cooperation will hang in a limbo of limited engagement if they are not anchored in a common narrative.

What, exactly, do I mean by this? I don't know exactly, but a good approximation of what I have in mind is really an imaginative framework of general identification, a kind of material for "common dreams" that may give all the citizens of Europe a certain minimum of existential meaning and emotional density, through which we may be able to recognize, foster, and nurture a commitment to something that transcends us as individuals with particular identities. I realize, of course, that such a construction is idealistic, hinged as it is on a search for balance between ethnic and cultural traditions on the one hand, and loyalty to a supranational, overarching political habitus on the other.

"Europeanism" would have to meet several demanding standards. It would have to include cross-generational continuity, perpetuated by a common cultural amalgamation of distinct ethnic traditions and reinforced by shared memory and the expectation of a common future. In other words, "Europeanism" would need to provide a symbolic order wherein a centripetal force might be able to counteract — though by no means abolish — the centrifugal forces of primary identification that one feels as a Pole, German, Catalan, Croatian, Scot, or Italian. The emotional charge in these building blocks of "Europeanism" in statu nascendi is, of course, undeniable. The various kinds of totalitarian nationalist abuse, which in both nineteenth- and twentieth-century Europe have often afflicted the mobilizing power of collective emotional ties will not, it appears, disqualify them from the equation.

In fact, the dominant political currents in Europe's "age of extremes" offer copious evidence that primary national identifications based on the shared self-perception of the ethnic, cultural, and linguistic heritage have almost always won the competition for popular allegiance, leaving other kinds of identifications, based on social class or profession or political persuasion, as distant "second best" options. 
"Europeanism," then, is little more, if at all, than an "invented tradition" which contains a fragile hope that its far-reaching, inclusive, utopian agenda might appeal to a majority of the citizens and peoples of Europe. So far, alas, precious few efforts have been made to facilitate a construction of such a common narrative. Among the numerous national, ethnic, and cultural traditions on the continent, "Europeanism" does not figure very high on anyone's list of identities. Moreover, it would not be too excessive to claim that the systemic and institutional integration of the European continent increasingly diverges from cultural integration.

With understandable regret I must state the obvious: the European Union has not yet succeeded in building a satisfactory series of images, values, and ideals that would transcend our immediate existence with all its difficulties and joys. "Europeanism" - as a constellation of aspirations, images, attitudes, convictions, and concepts that could serve as a source of individual inspiration and grant meaning to collective behavior-such "Europeanism" has not yet appeared on the horizon.

Nevertheless, I am convinced that it needs to be jointly contemplated and envisioned; otherwise, we all will find ourselves, rich West Europeans no less than poor East Europeans, in an undesirable situation. We will share institutions and agencies overseeing free-flowing financial and labor transactions, but our respective cultural spheres will remain condemned to an existence of reciprocal tolerance at best, that is to say, mutually encouraged passivity and a lack of active interest in regard to each other's immediate experience. Without a broad social consensus on the legitimate and, thus, publicly recognized presence of a common narrative in which Europeans can recognize themselves precisely as Europeans - and not exclusively as Poles, Germans, Lithuanians or Croatians-any attempt to construct such a narrative has to resort to abstract postulates.

Therefore, it is hardly surprising that the development of a "common mental framework," in which the rich experience of European cultural diversity could be symbolically integrated and remodeled, faces greater difficulties in both form and substance than the development of a "common market." John Stuart Mill, in Considerations on Representative Government, expressed this need in a classic formulation: "Among a people without fellow feelings, especially if they read and speak different languages, the united public opinion necessary to the working of representative government cannot exist."

Supranational identifications presuppose the need to recognize multiple loyalties. Inasmuch as the diversity of cultures has traditionally been a key element of Europe's greatness, this very diversity should be reinforced and celebrated. The forging of a new European identity as a complex, hybrid invented tradition calls for the recognition of the ineluctably multiple identities from which "Europeanism" might be designed. There is, of course, an element of wishful thinking here: multilayered identities should allow for the simultaneous celebration of local, national, and continental elements. Basic allegiances need not be exclusivist allegiances: it should not be impossible to be at the same time Catalan, Spanish and European.

Alas, the current negotiation on the shape and character of "Europeanism" is to a large degree guided by a profound distrust of particular and national identifications. Such distrust may be understandable, but it is epistemologically unacceptable in a globalizing world in which "Europeanism" is itself but a particular identity. That is why it is impossible to fashion any common ground of shared European identity if one is forced to eschew fecund local and particular markers.

If one shies away from the troublesome dialectics of particular and general, the only sustained answer will necessarily remain abstract and, ultimately, noncommittal. If one willfully avoids engaging the relevance of the cultural habits and values of the various nationalities of Europe, one's "Europeanism" will end up looking hollow, simulated, and insubstantial. Neither the authority of the European Commission nor the civic and ethnically blind character of Europe's supranational bodies possesses the ability to inspire citizens; these institutions are too hollow for any social mobilization and too immaterial to spark spontaneous affection, as John Keane has eloquently stated.

The enlarged EU, which lives on formal procedures, negotiation, and consensual compromise in the search of the common good, faces the most profound challenge: it must invent a new political design. Regardless of whether the future holds prospects for a confederate Europe or for a federation, a European democratic political culture must first be put in place and developed within member states themselves. This is especially true in the post-communist countries where democracy barely entered its early adolescence, where compromised files of the communist secret police still hold grip on public habits and ways of seeing the world are conditioned by decades of radical exclusivist regimes. There's little else to do but to remind ourselves of the simple fact: the democratic life in individual memberstates is the main precondition for fostering the democratic habits on a trans-national European level.

Alas, the kind of cultural tissue that would incorporate trust, consent, and solidarity in a common European life 
remains a long way off. From the vantage point of Eastern European experience, it is difficult to not see a Medusa of "traditional West" rearing its compromised head in a political pragmatism of some of the most prominent contemporary intellectuals. The idea of a pragmatically justified KernEuropa (core Europe) that would lead the European Union with relative independence from the anguished and, no doubt, cumbersome process of decisionmaking by consensus in an enlarged EU, this family of flexible membership, currently at 27 , this idea gives a dangerous credence to perhaps inevitable, but emphatically nondemocratic concept. It is best summed up as "Europe of two speeds", intimating politics of first and second class citizens. I am afraid that this trend only reinforces the historical discrimination of the traditional West against the peoples, languages, cultural traditions, and countries of the "Wild East", les petit pays de merde, as French diplomats are wont on saying.

The fact that, while Europe fidgeted, America finally, albeit belatedly, intervened in 1990s with military force in Bosnia and Kosovo complicates my personal dilemma all the more. My dilemma grows, in part, from the realization that many rejections of the American strategic dominion in Europe are permeated with an anti-American sentiment. It is this popular sentiment that has, after the end of the Cold War, replaced the structural source of fear that the Soviet Empire once represented. I would be blind, though, if I didn't recognize something else, too. The escalation of America's global military presence began with the legitimate and internationally legal attack on Afghanistan. I supported the move on the grounds of immediate causal link between the terrorist attack on 9/11 and the Talibansponsored boot-camps. America then upped the ante and occupied Sadam Hussein's Iraq. I opposed it on the grounds of lesser evil theory. America went into Iraq without broad international consensus. This was a huge backward step for transatlantic and international relations. Conceived on the grounds of straight-face lies, the war drove a wedge in the Western alliance. In fact, the "coalition of the willing" must properly be called a "coalition of the deceived", as the supporting nation-states were twisted into believing in the existence of Iraqi weapons of mass destruction.

The legacy of American ties to Europe, however, cannot be regarded in the contemporary context alone. A free and united Western Europe was, for Americans, the best form of security and peace after 1945. Lest be forgotten, Europe, over the course of the twentieth century, produced two World Wars, was the key geographical and political stage of the third, the Cold War, and then failed to decisively intervene in the wars in its backyard, i.e. former Yugoslavia. Each of these conflicts prompted in turn an American engagement on the European continent.

After the Cold War, America gradually ceased being seen as the exclusive guardian of the old continent. Instead, it became a mirror that Europe uses to correct and improve its self-image. At the same time, American strategic interest in European affairs has declined and America has begun to shift its focus to the former Soviet Central Asia and the Arab peninsula. Later, America would be naively appalled when faced with the fact that most of the European countries refused to join the United States in its Iraqi adventure. The American Secretary of Defense's notorious division of countries into "the Old Europe" and the "new Europe" according to the attitude toward the American occupation of Iraq, had a twofold character. On the one hand, it reveals a policy of "divide and conquer" that ultimately benefits America. On the other, it has functioned as a sobering statement that may one day work to Europe's benefit.

The division clearly illustrated at least the following: first, the governments of post-communist countries who have been practically given an ultimatum as to the adoption of acquis communautaire, without the chance to actively participate in a debate in all but the very last stages of enlargement process, now demand the right to have a voice in the common European house. Second, these governments and their publics have not forgotten the Cold War. It was during this period that a culture of mutual trust and solidarity between the Western and Eastern Europe lived a miserable existence, to put it euphemistically.

In order for Europe to achieve solid legitimacy as a pluralistic "open society", it must therefore significantly enhance the culture of trust. The culture of trust presupposes a democratic frame defined by solidarity. As with many other underlying social concepts, however, Western and Eastern Europe differ in their concept of the basic social bond.

In the modern Western world, the understanding of solidarity is pragmatic while in the East, the understanding of solidarity has been a moral one. Typical of the former is a concerted effort to join forces of all involved in order to attain a common goal which in turn reflects the common values and interests of participants. In the East, the prevailing belief is that solidarity is rooted in the imperative of unselfish assistance the stronger offers to the weaker, even if the only reward is a feeling of moral satisfaction.

There is no doubt that institutionalized solidarity played a key role in contributing to the modernization of Greece, Ireland, Spain and Portugal following their entry into the common European structures. Solidarity, alas, was 
since forced to yield to the demands of greater individual freedom and economic profits that have grown apace with global capitalism. The rebellion of the middle class against the continuation of guarantees for the social safety nets has been in Western Europe politically channeled into restrictions on the national budgets. The result? Solidarity, once the central pillar of social order, is now seen as a luxury which individual nations can, but are not obliged to, afford. It is no longer a crucial value. Instead, it has been pushed off to the sidelines.

Those who reject the necessity of solidarity's handshake and prefer to swear by the hidden hand of the market, however, must remain blind to what shape would this hand assume should it be visible: a fist with a pointed middle finger. Until it becomes a template of common belonging for people across European lands, without two-class discrimination, until then "free and united Europe" will remain what it is today: a noble dream. 